\title{
Learn about Probolinggo Municipal Government Partnership Pattern with Corporate CSR in Order to Re- alize Probolinggo City Environmen- tally Friendly
}

LOGOS

JOURNAL

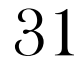

Received:April7,2018 Revised:April11,2018 Accepteed:April19,2018

\section{QURROTUL AINI $^{1}$, WAHYUDI ${ }^{2}$, MASDUKI $^{2}$}

${ }^{1}$ The Government Partnership Consultant

${ }^{2}$ Universitas Muhammadiyah Malang

sulis226@gmail.com

\begin{abstract}
The existence of industry in a city has an important role in the survival of society. Industry managers, as well as industrial environment are closely related to the regional government, because it is one of the planning of the city layout of an area. The importance of maintaining good relations has been realized by every company. How they foster good relations with the local government, the community, and the environment around the company. The existence of CSR (Corporate Social Responsibility) helps the company to establish such good relationships, besides the mutually beneficial relationships between companies and communities, companies with local governments that such things can help mitigate and minimize conflicts that occur. In the drafting of Regulation CSR, the DPRD and the government sometimes do not pay attention to the parties who become the object subject to the responsibility of Regulation, in this case the company. The government should understand the construction of corporate thinking, because it will be contradictory when on the one hand the region seeks to attract investors to invest their capital, while on the other hand due to too many rules, formal and informal costs, and even make investors reluctant to invest. In this research use social control theory, and social action, also institutionalism organizational. In this study using the type of qualitative research with phenomenology approach which of the phenomenon is doing an observation, then use field notes as well as in-depth interviews of informants who are selected based on purposive. The data obtained will be analyzed using qualitative descriptive technique andthedataischeckedforvaliditybytriangulation.
\end{abstract}

Key Words: Relation; CSR; Local Government. 


\section{ABSTRAK}

Keberadaan industri di suatu kota memiliki peran penting dalam kelangsungan hidup masyarakat. Pengelola industri, serta lingkungan industri sangat erat kaitannya dengan pemerintah daerah, karena merupakan salah satu perencanaan tata ruang kota. Pentingnya menjaga hubungan baik telah direalisasikan oleh setiap perusahaan. Bagaimana mereka menumbuhkan hubungan baik dengan pemerintah daerah, masyarakat, dan lingkungan sekitar perusahaan. Keberadaan CSR (Corporate Social Responsibility) membantu perusahaan menjalin hubungan yang baik, disamping saling menguntungkan antara perusahaan dan masyarakat, perusahaan dengan pemerintah daerah sehingga hal tersebut dapat membantu mengurangi dan meminimalkan konflik yang terjadi. Dalam perumusan CSR Perda, DPRD dan pemerintah terkadang tidak memperhatikan pihak-pihak yang menjadi objek yang menjaditanggungjawab Perda, dalam hal ini perusahaan. Pemerintah harusmemahami konstruksi pemikiran perusahaan, karena akan menjadi kontradiktif ketika di satu sisi wilayah tersebut berusaha menarik investor untuk menginvestasikan modalnya, sementara di sisi lain karena terlalubanyak peraturan, biaya formal dan informal, bahkan membuat investor enggan berinvestasi. Dalam penelitian ini menggunakan teori kontrol sosial, dan aksi sosial, juga kelembagaan organisasi. Dalam penelitian ini menggunakan jenis penelitian kualitatif dengan pendekatan fenomenologi yang mana fenomena tersebut melakukan pengamatan, kemudianmenggunakan catatan lapangan serta wawancara mendalam informan yang dipilih berdasarkan purposife. Data yang diperoleh akan dianalisis dengan menggunakan teknik deskriptif kualitatif dan data diperiksa validitasnya dengan triangulasi.

Kata Kunci: Hubungan; CSR; Pemerintah Daerah.

\section{INTRODUCTION}

The current environmental concerns are one of the most pressing issues of emergency in many countries. Environmental problems that occur can be caused by many things, either because of corporate behavior, society, or because of products that are less environmentally friendly.

Environmental pollution in the analysis of environmental jurists is due to the ambiguity of human action. Man has incorporated nature in his cultural life, but often forgets that he is part of the realm of hislife.

This is as disclosed in the research of Syamsuharya Bethan, the Application of the Legal Principles of Preservation of the Function of the Environment in National Industrial 
Activity an Effort to Save the Environment and the Life of the Generation, PT Alumni, 2008.

Daud Silalahi, states that:

"The concept of development that is being implemented now is not enough to consider only the cost benefit ratio, or market mechanism alone, also take into account the social costs that a rise (social cost)."

Environmental issues are not only a national strategic issue. This issue has also been discussed in a series of international discussions. However, the problem is that many local governments do not have enough formulation to manage the synergy of managing the environment by utilizing corporate CSR. Syamsuharya Bethan, Implementation of the Legal Principles of Preservation of the Function of the Environment in National Industrial Activity an Effort to Save the Environment and the Life of the Generation, PT Alumni, 2008.p. 196

This indication can be seen in various cases of poor waste management, waste, environmental sustainability in an area. The case of illegal mining is a specific example of how regional heads often ignore environmental issues in providing access toproductiveeconomiestotheircitizens.

Not only the issue of awareness and willingness, local government should also be more creative in handling environmental issues, whether the problem of waste, waste, natural sustainability, socio-cultural behavior andsoforth, as detailed in the Act 23 of 2014 on Government Areas on Spatial Planning and the Environment.

As many of the stories contained on the site http:// www.greeners.comention that the awareness and creativity of local governments in dealing with environmental issues is still minimal. Simultaneous government cooperation with the public, private and corporate is still running yet synergistic. Creativity is in line with the intention and willing ness of the 
Vol. 1 No.1 March2018

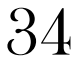

government itself in realizing the green and environmentally friendly (http://www.greeners.co/berita/atasi-masalahsampah-pemerintah-daerah-diminta-kreatif-dan-inovatif/).

Probolinggo city government has successfully run various CSR programs in order to realize and rearrange environmental issues. Quoted from a paper written by the mayor of Probolinggo period 2014-2019, Rukmini Buchori write in a paper about his vision to make the city of Probolinggo as a City of Environment, City Competitiveness Era ASEAN Community 2025.In this paper Rukmini provides a description related to the original plan to build braided partnership CSR with BPPT, APEKSI, GIZ, USAID, IUWASH,MERCY CORPS Indonesia, PERTAMINA Foundation (Rukmini, Rao, \& Rao, 2013).

Not only rely on the budget of the city budget Probolinggo, the government also mengkusn strategic cooperation plan with be rabgai company to realize the dream of Probolinggo become environmentally friendly city. The strategic design of city government cooperation Probolinggo as stated in Probolinggo city mayoral paper 2014-2019, Rukmini Buchori is as in the chart below.

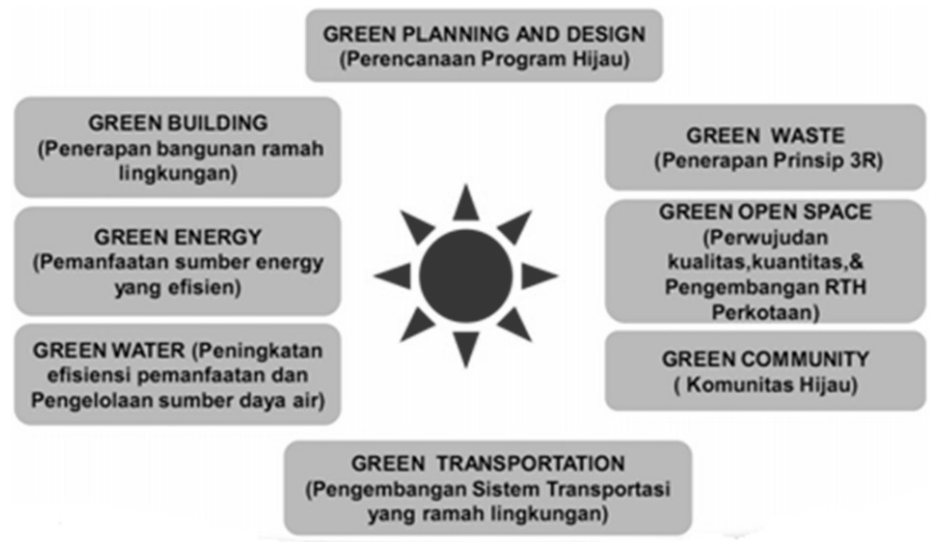

Figure 1. The strategic design of city government cooperation Probolinggo 
The design of the strategy and the creative effort of Probolinggo government provides various realization activities of environmentally friendly city of Probolinggo, with a big mission Towards Probolinggo Environmental Friendly City, City of Competitive Era ASEAN Community 2025.

\section{LITERATURE REVIEW}

Corporate Social Responsibility or so-called Social responsibility is the actions and policies of the company in interacting with its environment based on ethics (Purwanto \& Nursam, 2006). Corporate Social Responsibility is basically a necessity for corporates to be able to interact with local communities as a form of society as a whole. The need for corporations to adapt and to derive social benefits from their relationship with local communities, a social advantage of trust. (Bambang \& Melia, 2013).

According to (Kotler \& Lee, 2005) in (Solihin, 2008) defines Corporate Social Responsibility Corporate Social Responsibility is a commitment to improve community wellbeing through discretionary business practices and the contribution of corporate resources"

More emphasized on discretionary meaning CSR is solely a company commitment that voluntarily contributes to improve the welfare of the community and not a business activity required by law and legislation such as tax oremployment.

CSR as business acts in socially acceptable behavior when accounting and account for balance diverse take holder interest (Maignan \& Ferrell, 2004). In this definition it is emphasized that the need to pay attention tothe interests of diverse stakeholders in every decision and action taken by business actors through socially responsible behavior (Susanto, Susanto, Wijanarko, \& Mertosono, 2007).

Disclosure of corporate social responsibility is thecommitment and ability of the business community to give 
Vol. 1 No.1 March2018

36 awareness, carry out social obligations, build togetherness, conduct social welfare programs or activities or social development as a form of social solidarity and maintain the balance of the surrounding ecosystem (Ministry of Social Affairs, 2007 in Business Magazine and CSR, 2007; 28).

Social responsibility is the acceptance of management to the obligation to consider profit, customer satisfaction, and social welfare as a worthy value in evaluating company performance (Boone \& Kurtz, 2002).

\section{RESEARCH METHOD}

In this research use qualitative descriptive research. This study aims to describe the existing CSR in Probolinggo district. This research uses case study approach because the focus in this research is to answer how CSR in Probolinggo can realize environmentally friendly city of Probolinggo. Criteria in determining the subject of research include: Probolinggo city government, Owners of shares or companies, and Society. Data collection techniques in this study using observation, in-depth interviews, and documentation. Then the data is analyzed using triangulation. This process is done to compare, measure the results of interviews between each research subject, also to know the validity of the dataitself.

\section{RESULT AND DISCUSSION}

In social reality, our society does not really care about the environment in which it lives. Many community behaviors and activities not only show their indifference to the environment, event their behavior is destructive to the environment. To build the behavior of the people who care about the environment requires a clear policy from the government by involvingall parties and done continuously consistently. The government should set an example and disseminate positive behavior from various community groups (best practice). 
The government must really care and consolidate the special and creative plans to become the pioneer of environmental awareness mobilization. Because the environment is a very important factor in human survival. Therefore, maintaining and managing the environment properly is a must. If the environment continues to be ignored and destroyed, people will not only lose, but alsoperish.

\section{Engage Private Participation in the Company}

The strategic plan of the city of Probolinggo in order to realize the dream of becoming a leader in the environment in ASEAN Community 2025 has been designed since 2005. It is as stated in Probolinnggo Green Planning and Design with the Local Regulation No. 2 Th. 2010 on the Spatial Plan of the Year 2009-2028, continuous sustainability of MUSRENBANG with the involvement of the ward community, drafting the Integrated Strategy Plan to address Climate Change, Green City Local Action Plan, Local Action Plan for Greenhouse Gas Emission Reduction, Urban level sanitation planning (book white sanitation), the determination of city-level environmental regulations and ongoing efforts of cooperation with companies and the private sector (Rukmini et al., 2013).

Corporate involvement through CSR activities in order to mobilize environmental awareness in Probolinggo region is based on government invitation to private sector to take responsibility by promoting good corporate governance based corporate governance. Because with these principles, the company can always be loved by consumers and society. Infect, capitalizeed goodness created by the company, consumers will still be loyal, even though the company was plagued by the crisis. 


\section{Establishing the Corporate Social Responsibility Forum of Probolinggo City}

On January 21, 2014 Social and Cultural Affairs Bappeda Kota Probolinggo held a formation of corporate social responsibility forum of Probolinggo City. Meetings were invited and attended by various CSR donor companies in Probolinggo City. The event was held at Hotel Bromo View.

The event was organized by the CSR corporate forum. The result of the meeting gave an agreement regarding the figure of the forum chairman, Gatot Is woyo from PT. KTI. The stewardship of the forum is complemented bysecretaries, treasurers and other administrative apparatuses, including some Pok ja, such as Pokja Pendidikan, Pokja Kesehatan, Pokja Ekonomi, Sosial Masyarakat, Pokja Kamtibmas and Lingkungan Hidup. All working groups work in accordance with the formulation of work program forum that lasted 3 years.

The forum is the first time CSR Forum was formed in probolinggo. Now in 2017, Probolinggo CSR Forum has inaugurated the new ketyua on May 24, 2017. The event was held in Puri Manggala Bhakti Building, Probolinggo Mayor's Office,Workshop and Inauguration of Corporate Social Responsibility Forum (CSR) of Probolinggo City for the period of 2017-2020.

The effectiveness of CSR forums such as the implementation of CSR funding for various activities of social concern, especially related to the environment. For example, in 2017 Jasa Marga has provide dassistance of Rp.1 Billion programmed for MCK for 50 families, electricity for 100 families, and basic food for 110 families.

The results of successful CSR programs such as assistance for Pilang residents in the form of mangrove seed business that can be sold and assisted to institutions, and groups of 
mangrove seeds that have managed to create green coastal areas. The effectiveness of CSR in Probolinggo city is reflected in the success of CSR Probolinggo City as the first rank in 2017 in the best fish processing fortoddlers.

\section{Basic Principles: Involving Communities}

Kota Probolinggo became one of the five winners of Indonesia Green Award (IGRA) 2012 Category City. Probolinggo city has a score of 85.30, under the city of Surabaya is ranked first and Yogyakarta in second place.

The success of Probolinggo city government is not easily achieved. It takes a strong commitment from local governments to realize the dream of becoming a sustainable city through Green City. The basic formula, as delivered by the mayor of Rukmini, is the unity of motion with legislators, private CSR and community involvement.

In realizing this Green City Action Plan, the government has a basic principle of promoting community involvement and empowering local resources. Community involvement includes synergizing the city government program with CSR (corporate social responsibility) program. Every three months the Probolinggo city government mates coffee morning by inviting companies, banks, legislative representatives, government and CSR forums. The activity is effective to involve various public, private and corporate leprosy in order to make Probolinggo as Green City.

\section{Congress Pedicab Riders}

Environmental issues are closely related to the social behavior of the community. For that, social group who sebody in the community should get a touch of government. Because of these groups various perceptions can beunified in order to achieve a shared dream.

One of the creative initiatives of Probolinggo city government is to initiate and facilitate the Congress of Becak. 
Vol. 1 No.1 March2018

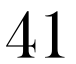

This activity was quite successful by presenting pedicab drivers of Probolinggo city up to 4,986 pedicab drivers. The goal is the active involvement of pedicab drivers to make Probolinggo City as a comfortable, orderly, and greencity.

So also, with other social groups. In the city of Probolinggo then grow various groups or Forum cares such as Spatial Care Society (Formastaru), Waste Management Network Forum (Forjamasa), Sustainable Development Council (DPB), paguyuban or boarding school, Forum Kota Sehat, Paguyuban Peduli Sampah (Papesa) and others etc.

\section{Communicative, Key to Realize Green City Probolinggo}

Urban as a man-made habitat with all its activities has various problems, ranging from waste, green open space, population, transportation, energy, water, and others. The problem is the fruit of conventional development. To that end, thedevelopment of a city must be changed paradigm to be environmentally sound development through the application of the concept of green city (green city).

To realize the concept of the green city, BPPT and the Government of Probolinggo City signed a Joint Agreement on Assessment, Application and Technology of Supporting Regional Development of Probolinggo Municipality" on11 April 2014 at BPPT Building, Jakarta.

Cooperation with BPPT is not running suddenly. Communication and seriousness Probolinggo city in building Green City has been present since 2008. In that year Probolinggo Government and BPPT have often exchanged informationin terms of optimizing environmental management. Such sustainability realiasasi such as BPPT cooperation with the government of Probolinggo in 2014 which is focused on environmental management which includes the development and application of technology of solid and liquid waste management, mangrove conservation, and development of greencity. 
The communicative concept becomes an effective way of Probolinggo city government in implementing various policies related to the environment. Whether it is communication with the central government, provincial, community, private, companies and all agencies/institutions that have a vision and mission in line to realize Green City is environmentally friendly.

The result is probolinggo city revelation as a real Green City JOURNAL makes the city Probolinggo increasingly aaddicted' basing the development of the city as a green city and environmentally friendly. Raihan Probolinggo city received Green Awards based on Probolinggo city implementation activities with various jargon, such as Probolinggo Kota SeribuTaman, Development of Environmental Study Park (TWSL), integrated waste management, planting mangrove as coastal community empowerment, utilizing methane gas and developing KB2S2 program (Kali Banger Bersih Sehat Sejahtera).

\section{CONCLUSION}

From the discussion description Deepening Probolinggo Government Partnership Pattern with Corporate CSR InOrder to Realize Probolinggo Environmentally Friendly, it can becon cludedas follows: (1) The process of involving companies through CSR to realize the green and environmentally friendly Probolinggo city is a must. Because the CSR can be empowered various corporate contributions, especially related to funding; (2) Involving the community is the basic principle of success in planning, realization and follow up activities to realize the city of Probolinggo as a green and environmentally friendly city;(3) Environmental problems are closely related to the social behavior of the community. Therefore, the ability to group the community and give the role and position of each group to be able to play proportional role in accordance with the role and position; and (4) There is a need for comprehensive communications, both at the central government,private 
Vol. 1 No.1 March2018

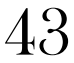

sector, companies and communities to realize the city of Probolinggo as Green City. Because urban as a man-made habitat with all its activities have various problems.

\section{REFERENCES}

Bambang, R., \& Melia, F. (2013). CSR (Corporate Sosial Responsibiliti): Rekayasa sains. Bandung.

Boone, L. E., \& Kurtz, D. L. (2002). Pengantar Bisnis. Penerjemah Ferdiansyah AnwarErlangga. Jakarta.

Kotler, P., \& Lee, N. (2005). Best of breed: When it comes to gaining a market edge while supporting a social cause,"corporate social marketing” leads the pack. Social marketing quarterly, 11(3-4), 91-103.

Maignan, I., \& Ferrell, O. (2004). Corporate social responsibility and marketing: An integrative framework. Journal of the Academy of Marketing science, 32(1), 3-19.

Purwanto, B., \& Nursam, M. (2006). Gagalnya Historiografi Indonesiasentris?!: Ombak.

Rukmini, M., Rao, G., \& Rao, R. (2013). Effect of cold pretreatment and phytohormones on anther culture efficiency of two Indica rice (Oryza Sativa L.) Hybrids-Ajay and Rajalaxmi. Journal of Experimental Biology and Agricultural Sciences, 1(2), 69-76.

Solihin, I. (2008). Corporate Sosial Responsibility: from Charity to Sustainability, penerbit Selemba Empat: Jakarta.

Susanto, A., Susanto, P., Wijanarko, H., \& Mertosono, S. (2007). The Jakarta consulting group on family business. Jakarta: The Jakarta Consulting Group. 